\title{
The Effect of Blended Learning based on Edmodo Application to the College Students' Learning Outcome (Case Study: The Development of Macroeconomics Teaching Material of Small Group Test Phase)
}

\author{
Putri Sari M.J. Silaban ${ }^{1 *}$, Joko Suharianto ${ }^{2}$, Dede Ruslan ${ }^{3}$ \\ \{poetrisilaban@yahoo.com¹,djoko@unimed.ac.id ${ }^{2}$,dras_ruslan@yahoo.com ${ }^{3}$ \} \\ Economics Faculty, Universitas Negeri Medan ${ }^{1,2,3}$ \\ *poetrisilaban@yahoo.com
}

\begin{abstract}
This research was purposed to find out the effect of Blended Learning based on Edmodo Application to the college students' learning outcome. It was done as a part of small group test phase on the research and development of macroeconomics teaching material at Economics Faculty of Universitas Negeri Medan. This research was applied in experimental research design. The populations of this research are the third semester students of Macroeconomics Theory subject at Economics Education Study Program that consisted of three classes. The samples of this research are the students of C class as many as thirty students. The technique of the data analysis was statistic parametric paired sample t-test approach by testing the normality assumption and homogeneity of the previous data. Validation instrument is using expert judgment. Based on the result of this research, it can be concluded that there was significant different of students' learning outcome before and after the treatment of Blended Learning based on Edmodo Application at Macroeconomics Theory subject at significant level alpha 5\%. The mean score of the post test was $(75,5)$ higher compared to the mean score of the pre-test $(35,5)$. Generally, the treatment of Blended Learning based on Edmodo Application to the students' learning outcome at Macroeconomics Theory subject gave effect at the middle category with $\mathrm{N}$-gain score $0,62(0,3 \leq \mathrm{g} \leq 0,7)$. In order to improve the efficiency of Blended Learning, it was suggested to previously observe the students' learning aid, the ability of the teachers in designing content and the Blended Learning system mastery, and also in observing the students' satisfactory aspects.
\end{abstract}

Keywords: Blended learning, teaching material and learning outcome.

\section{Introduction}

The means of the improvement of the learning outcome quality had been done continuously to achieve alumnus quality which relevant with the development and challenge of the era. It had been done at all levels of education, start from the elementary up to higher education.

The challenge of education nowadays is more complex by the development of the role and technology. Information and technology affect the education activities massively. The role of lecturers has been rubbed down by the simplicity of getting information from the internet. In the upcoming era, the role and the presence of lecturers in the class will give more challenge and need higher creativity. New information and knowledge spread easily and can 
be easily accessed for anyone in need. Education is facing great disruption. All development of technology must focus on the better learning outcome.

There are factors which can affect learning outcome. The success of learning must have two factors which are the internal and the external factor like (1) emotional intelligence; (2) interest and talent; (3) learning strategy; (4) means and infrastructures; (5) motivation and prestige; (6) learning ways; (7) curriculum; and (8) intellectual intelligence [1].

One way to improve learning outcomes is by adjusting of relevant learning strategy. In improving learning effectiveness by choosing suitable learning strategy which based on the learning condition which predicted can affect learning outcome to be easy for students [2]. In the effort of the students' learning is the problem of the presentation of learning aids with the learning strategy in use [3].

One of the means of adaptive learning strategy with the role of technology is blended learning. The term blended learning has been used by experts in term of hybrid course, blended e-learning, and hybrid learning. In this research, the effort of improving students' learning outcomes specially at Macroeconomics Theory Subject which has been done by the improvement of learning aids of the subject through a series of research and development of learning aids based on Borg \& Gall [4]. Learning aids which have been revised based on the suggestion of validators to be tested to students by using relevant learning strategy with technology development which is blended learning.

Blended Learning refers to the combination of learning strategies between face to face learning strategy and computer learning strategy whether online or offline which conducted through e-learning [5]. Historically, tertiary education has used the term hybrid program to illustrate the learning combination of face to face and long distance learning [6].

Blended Learning in this research is considered as a face to face learning interaction and learning with online approach. Online learning in this research will be done by Edmodo Application. Edmodo is a social media based on learning management system (LMS). Edmodo facilitates teachers, students, provides save place to communicate, collaborate, share contents and learning applications, home work for students, discussion in virtual class, online test, providing scores, etc. Edmodo is very comprehensive as a course management system like Moodle, the different is that the faster access and handy usage [7]. Edmodo has three functions in the learning process which are the replacement function, accompaniment, and complement [8].

The previous research showed that there was significant academic ability improvement to the students who treated by using face to face learning combined with learning technology online and offline compared to the conventional learning [9].

The learning planner needs to find out the elements and the perfect blend in the blended learning environment, so that it can utilize benefits of asynchronous by keeping the quality of interaction in the class through face to face $[10,11,12]$. For that reason, further challenge is how to construct good blended learning strategy, easy, interesting learning contents which give real advantage to the institution, lecturers, and students, because the main purpose of technology improvement is to facilitate humans with easier access.

\section{Research Method}

This research had been conducted for students of Economics Education Study Program in 2019/2020 academic year. The populations of the research are the third semester students of 
Macroeconomics Theory subject that consisted of three classes. The samples of this research are the students of $\mathrm{C}$ class as many as thirty students.

This research used the learning outcome instrument of Macroeconomics subject with the subject matter of Macroeconomics, Money, Inflation, and Jobless which had been validated by Macroeconomics experts Dr. Arwansyah, M.Si (Lecturer of Macroeconomics Theory Subject FE Unimed) and Dr. Eko Wahyu Nugrahadi (Lecturer of Introduction to Macroeconomics Subject FE Unimed).

This research was applied in experimental research design with one group sample with the design of pretest - action - post-test. In the beginning, a problem discourse based on empirical data was given then continued by the blended learning based Edmodo by giving learning material, video, related journal, and relevant hot news. At the end of the second meeting, online post-test was given in CBT concept (computer based test).

The technique of data analysis of this research was paired sample t-test with the following hypotheses:

Ho: There is no difference of learning outcome before and after the treatment of the blended learning strategy based Edmodo at Macroeconomics Theory subject.

Ha: There is difference of learning outcome before and after the treatment of the blended learning strategy based Edmodo at Macroeconomics Theory subject.

The primary data that was used to improve the learning outcome was the pretest and posttest data. The data was then analyzed to see the result of the test, statistic descriptive, assumption test, hypotheses test, and also N-gain score. N-gain score was analyzed to see the effect of blended learning strategy based Edmodo to the students' learning outcome. N-gain was calculated by applying Hake's formula [13]:

$$
\mathrm{N}-\text { Gain }=\frac{\text { Post test Score }- \text { Pretest Score }}{\text { Maks. Ideal Score }- \text { Pretest Score }}
$$

The category of the $\mathrm{N}$-gain score is as follow:

Table 1. Division of Gain Score

\begin{tabular}{lll}
\hline No & N-Gain Score & Category \\
\hline 1 & $\mathrm{~g}>0,7$ & High \\
2 & $0,3 \leq \mathrm{g} \leq 0,7$ & Middle \\
3 & $\mathrm{~g}<0,3$ & Low \\
\hline
\end{tabular}

\section{Result and Discussion}

Research data were collected using instruments as stated in the research methodology section. The results of data collection are continued with the analysis as described in the following section. The result of the pretest and posttest in this research was as follow:

Table 2. Descriptive Data Research Paired Samples Statistics

\begin{tabular}{llccrr}
\hline \multicolumn{5}{c}{ Paired Samples Statistics } \\
\hline & Mean & N & Std. Deviation & Std. Error Mean \\
\hline Pair 1 & Data Pretest & 35.5000 & 30 & 6.86696 & 1.25373 \\
& Data Posttest & 75.5000 & 30 & 7.35199 & 1.34228 \\
\hline
\end{tabular}


Based on the above table, the mean result of the students' pretest was 35,5 , after the treatment of the blended learning strategy based Edmodo, the posttest was 75,5. Based on the result, there was significant improvement of 40 point or $113 \%$. Before testing the hypotheses, it was a need to do the normality and homogeneity assumption test with the result as follow:

Table 3. Normality Test

\begin{tabular}{lcccccc}
\hline & \multicolumn{3}{c}{ Kolmogorov-Smirnov $^{\text {a }}$} & \multicolumn{3}{c}{ Shapiro-Wilk } \\
& Statistic & df & Sig. & Statistic & df & Sig. \\
\hline \multirow{2}{*}{ Data Pretes } & .155 & 30 & .064 & .936 & 30 & .073 \\
Data Postest & .139 & 30 & .141 & .955 & 30 & .229 \\
\hline a. Lilliefors Significance Correction & & & & &
\end{tabular}

Based on the normality test table, it was found out that both groups pretest and posttest had significant score $>0,05$, then it was concluded that both groups distributed normally.

Table 4. Homogeneity Test

\begin{tabular}{lllll}
\hline Learning Outcome & & & \\
Levene Statistic & & df1 & df2 & Sig. \\
\hline & .103 & 1 & 58 & .749 \\
\hline
\end{tabular}

Based on the homogeneity test table, it was found out that pretest group and posttest group had significant score $0,749>0,05$, then it was concluded that both groups were homogeny.

After finishing the assumption test, then the hypotheses test was tested with the result as follow:

Table 5. Hypotheses Test Paired Samples Test

\begin{tabular}{|c|c|c|c|c|c|c|c|}
\hline & \multicolumn{3}{|c|}{ Paired Differences } & \multirow{2}{*}{$\mathrm{T}$} & \multirow{2}{*}{ df } & \multirow{2}{*}{ Sig. (2-tailed) } \\
\hline & & Mean & Std. Dev & Std. Error Mean & & & \\
\hline Pair 1 & Pre - Post & -40 & 10.2 & 1.87 & -21.36 & 29 & .000 \\
\hline
\end{tabular}

Based on the hypotheses test table above, it was found out that the $t$ count was 21,36 with the significant score $0,000<0,05$, then Ho was rejected. It means that there was significant different of learning outcome before and after the treatment of blended learning strategy based Edmodo at Macroeconomics Theory at alpha level 5\%.

To see the impact of the blended learning strategy to the students' learning outcome, the $\mathrm{N}$-gain score was applied with the result 0,62 . Based on the $\mathrm{N}$-gain score criterion, it was concluded that the impact of blended learning strategy to the students' learning outcome in this research was effected at the middle level between $0,3 \leq \mathrm{g} \leq 0,7$.

\section{Discussion}

Based on the result of this research, the mean score of the posttest in this research is 75,5 higher than the mean score of the pretest 35,5. Then based on the hypotheses testing it could be concluded that there was significant different of learning outcome before and after the treatment of blended learning strategy based Edmodo at Macroeconomics Theory at alpha level $5 \%$. 
The result of this research was compatible with the previous research, who took the research subject of grade seven F MTs Negeri Magelang in 2015/2016 school year that consisted of 29 students [14]. The research was done by using classroom action research methodology by applying blended learning with Edmodo application based PDEODE learning strategy. The result of this research was that the treatment of blended learning with Edmodo application based on PDEODE learning strategy improved the students' learning achievement. It was proven by the students' learning completeness percentage as in the pre-cycle into cycle one improved $31 \%$, cycle one into cycle two improved $62 \%$, and pre-cycle into cycle two improved 93\%.

The result of this research had strengthen the previous research showed that there was significant academic ability improvement to the students who treated by using face to face learning combined with learning technology online and offline compared to the conventional learning (face to face) [9].

The development of blended learning model could improve students' learning outcome and easier to understand the material whether through traditional learning or e-learning [15].

In line with above research, there is a research where the research subjects were the second semester of Economics Development at Universitas Negeri Malang consisted of 104 participants [16]. All of the participants were then divided into two groups which were experiment group (blended learning) and control group (face to face). Based on the data analysis, it was concluded that the application of blended learning strategy was significantly better that the face to face learning strategy.

At higher education, blended learning usually constructed from face to face meeting once a week where students do online learning to finish group project and another tasks [17]. Blended learning becomes one of the new learning strategies that provides many benefits to students and also as a form of informational technology support for new learning model as well [18].

It was proven from the result of a research that shows the benefits of blended learning strategy which include the success of (a) accomplishing the learning purpose, (b) changing learning habit that usually lecturer centered into students centered, (c) balancing the students' independency in learning and also to motivate the students to discipline themselves in learning $[6,19,20,21,22]$. Blended learning was a creative and innovative learning strategy that could improve students' learning independency [23].

Many researchers deal with the application of blended learning. Generally, the research focused on the students' performance, students' attitude, and the satisfaction of learning of face to face, online, or blended learning [6]. Various opinions from the result of the research can be classified into five main tendencies including learning effectiveness, students' satisfactory, faculty's satisfactory, financial efficiency and learning access, and also students' ability improvement [24].

Based on the $\mathrm{N}$-gain score that obtained from this research which was 0,62 , it means that the impact of blended learning strategy to the students' learning outcome was at the middle level. However, not all students like the application of blended learning model, it means that the level of satisfaction among the students may be different. The result of the observation of this research described that around one third participants had less satisfactory by the application of blended learning. This was likely happened because of the lack of learning facilities such as laptop or smartphone with sufficient internet quality. This is a classic problem considering the application of this learning strategy in developing countries where people's income is dominated from middle to low range. That is why, it is undebatable that not all of the students' learning facilities supported well. 
This thing is convinced by the previous research that the satisfactory level of students with blended learning has an important role [25]. That is why the focus of the research must be at the main factors that affect the students' satisfactory level in blended learning environment. There are six dimensions that includes (1) students, (2) teacher, (3) institution, (4) technology, (5) design, (6) environment that becomes the indicator of the students' satisfactory specially at the component of e-learning in blended learning environment. That is why, it might be more strategic to stress at the design of implementation of e-learning in the blended learning environment, especially for the younger students.

This is different with the previous research, which took the empirical view learning area of three comparisons which were (1) face to face, (2) online, (3) blended learning at the material of Introduction to Managerial Accounting [26]. The research compared the mid-term test result, final test result, and the sum of the final score of the students at the course which was taught by the same instructor by using blended learning, face to face, and the use of online media. The research used variance test analysis to determine whether there was significant different to the students' performance result at the course. The result of this research showed that there was no significant different among the three different learnings environment.

Various result of the previous research clarified the important role of technology in education. However, technology is only a tool where the learning quality in the class and the interaction between lecturers and students are the essence. For that reason, lecturers must master the main point of applying blended learning strategy well.

Based on above analysis to improve the optimization result of the application of blended learning strategy, then firstly need to pay attention to the learning facilities support that the students have, the ability of teacher in designing content and blended learning system mastery, and specifically to pay attention to the satisfactory level of students in applying this learning strategy.

\section{Conclusion}

Based on the result of the research, it was concluded that there was significant different of students learning outcome before and after the treatment of blended learning strategy based Edmodo of Macroeconomics Theory at Alpha level 5\% with the post-test mean score of 75,5 higher compared to the pre-test mean score of 35,5. The impact of the application of the blended learning strategy to the students' learning outcome of Macroeconomics Theory subject was at the middle category with the $\mathrm{N}$-gain score of 0,62 or between $0,3 \leq \mathrm{g} \leq 0,7$.

Generally, the application of blended learning strategy based Edmodo was effective to improve the students' learning outcome. In order to support the successful of this learning strategy was not all about technology mastery and good learning activeness, but also about the availability of learning. However, the problem was not all students had the facilities. That is why, based on the result of the observation to the sample of the research, there were some students who disagreed the application of blended learning strategy and preferred face to face concept conventionally. For this reason, it is necessary to consider the readiness of facilities and infrastructure, especially in terms of students to support the effectiveness of blended learning strategy.

In addition, it is necessary to increase the capacity of lecturers through various socialization and training to improve relevant IT-based learning technology, so that lecturers 
would be able to provide relevant and interesting blended learning content to overcome the challenge of 4.0 industrial revolution era nowadays.

\section{References}

[1] Azhar, Arsyad. Media Pembelajaran. Raja Grafindo Persada. Jakarta. (2002).

[2] Kemp, E.Jerrold. The Instructional Design Proces, Proses Perancangan Pengajaran. Penerbit ITB. Bandung. (1994).

[3] Dimyati. Belajar dan Pembelajaran. Rineka Cipta. Jakarta. (2013).

[4] Sugiyono. Metode Penelitian Kuantitatif, Kualitatif dan R\&D. Alfabeta. Bandung. (2010).

[5] Driscoll, M. Blended Learning: Let's Get Beyond the Hype. LTI Magazine. (2002).

[6] Osguthorpe, R., \& Graham, R. Blended Learning Environments: Definitions and Directions. The Quarterly Review of Distance Education. (2003).

[7] Dharmawati. Penggunaan media e-learning berbasis edmodo dalam pembelajaran english for business. QUERY: Jurnal Sistem Informasi. (2017).

[8] Ainiyah, Z., \& Puspasari, D. Penggunaan edmodo sebagai media pembelajaran elearning pada mata pelajaran otomatisasi perkantoran di SMKN 1 Surabaya. Jurnal Administrasi Perkantoran (JPAP). (2015).

[9] Hiltz, Roxanne, S., Turoff, \& Murray. Education Goes Digital: The Evolution of Online Learning and the Revolution in Higher Education. Communications of the ACM. (2005).

[10] Kerres, M. \& DeWitt, C. A Didactical Framework for The Design of Blended Learning Arrangements. Journal of Educational Media. (2003).

[11] Martyn, M. The Hybrid Online Model: Good Practice. Educause Quarterly. (2003).

[12] Reay, J.E. Blended Learning A Fusion for Future. Knowledge Management Review. (2003).

[13] Meltzer, D.E. The Relationsip Beetween Mathematics Preparation and Conceptual Learning Gains in Physics: Posisible "Hidden Variable" in Diagnostic Pretest Scores. American Journal of Physics. (2002).

[14] Ekawati, Noor Emmy. Penerapan Blended Learning dengan Aplikasi Edmodo Berbasis Strategi Pembelajaran PDEODE Untuk Meningkatkan Prestasi Belajar Siswa. Jurnal Ilmiah Pendidikan MIPA. (2018).

[15] Isa, Yumanto. Pengembangan Model Blended Learning Mata Kuliah Perencanaan Teknologi Pembelajaran, Teknologi Informasi dan Komunikasi. Jurnal Teknologi Pendidikan. (2015).

[16] Sudarman. Pengaruh Strategi Pembelajaran Blended Learning Terhadap Perolehan Belajar Konsep Dan Prosedur Pada Mahasiswa Yang Memiliki Self-Regulated Learning Berbeda. Jurnal Pendidikan dan Pembelajaran. (2014).

[17] A. Januszewski \& M. Molenda. Educational technology: A definition with commentary. Routledge. New York. (2008). 
[18] C. Bonk \& C. Graham. The Handbook of Blended Learning: Global Perspectives, Local Designs. Pfeiffer. San Francisco. (2006).

[19] Murphy, P. The Hybrid Strategy: Blending Face-to-Face with Virtual Instruction to Improve Large Lecture Courses. (2003).

[20] Riffell, S. \& Sibley, D. Learning Online: Student Perceptions of a Hybrid Learning Format. Journal of College Science Teaching. (2003).

[21] Voos, R. Blended Learning: What is It and Where Might It Take Us?. Sloan-C. (2003).

[22] Dziuban, C.D., Hartman, J., \& Moskal, P.D. Blended Learning. ECAR Research Bulletin. (2004).

[23] Sutisna, Anan. Pengembangan Model Pembelajaran Blended Learning pada Pendidikan Kesetaraan Program Paket C dalam Meningkatkan Kemandirian Belajar. Jurnal Teknologi Pendidikan. (2016).

[24] Lorenzo, G. \& Moore, J. C. The Sloan Consortium Report to The Nation: Five Pillars of Quality Online Education. (2002).

[25] Won Sun Chen1 \& Adrian Yong Tat Yao. An Empirical Evaluation of Critical Factors Influencing Learner Satisfaction in Blended Learning: A Pilot Study. Universal Journal of Educational Research. (2016).

[26] Aly, Ibrahim. Comparison of Students' Performance in a Managerial Accounting Course Taught in Blended Learning, Traditional Classroom, \& Online Setting. A Journal of International Academy of Business Disciplines. (2016).

[27] Archambault, J. The Effect of Developing Kinematics Concepts Graphically Prior to Introducing Algrebaic Problem Solving Techniques. Action Research for The Master Natural Science Degree with Concentration in Physics. Arizona State University. (2008).

[28] Graham, C.R., Allen, S., and Ure, D. Blended Learning Environments: A Review of The Research Literature. (2003).

[29] Heinze, A., Procter, C \& Scott, B. Use of Conversation Theory to underpin Blended Learning. International Journal of Teaching and Case Studies. (2007).

[30] C. J. Bonk \& C.R. Graham. Handbook of Blended Learning: Global Perspectives, Local Designs. Pfeiffer Publishing. California. (2006).

[31] Sari, A. R. Strategi blended learning untuk peningkatan kemandirian belajar dan kemampuan critical thinking mahasiswa di era digital. Jurnal Pendidikan Akuntansi Indonesia. (2013).

[32] Uzun, A. \& Senturk, A. Blending Makes the Difference: Comparison of Blended and Traditional Instruction on Student's Performance and Attitudes in Computer Literacy. Contemporary Educational Technology. (2010). 